\title{
Fear and cultural background drive sexual orientation prejudice in France
}

\author{
N.-M. Fronhofer ${ }^{1,2^{*}}$, C. Herbert ${ }^{2}$, V. Durand ${ }^{1}$, A. Alvergne ${ }^{1,3}$, M. Raymond ${ }^{1}$, and M. Barkat-Defradas ${ }^{1}$ \\ 1: ISEM, University of Montpellier, CNRS, EPHE, IRD, 34095 Montpellier, France \\ 2: Department of Applied Emotion and Motivation Psychology, Institute of Psychology and \\ Education, Ulm University, 89081 Ulm, Germany \\ 3: School of Anthropology and Museum Ethnography, University of Oxford, Oxford OX2 \\ 6PE, United Kingdom \\ *: n.fronhofer@gmail.com
}

Sexual stereotyping and its negative consequences remain major issues in Western societies. Sexual prejudice is often nurtured by the socio-cultural background in which individuals grow up, making differences in sexual prejudice especially visible in multicultural societies. In France, one example of such a multicultural society with a high number of French citizens with recent migratory background from Maghreb, the socio-cultural basis of sexual prejudice has largely remained unexplored.

Here, we report results from an experimental study investigating sexual stereotyping in France. We base our analyses on an elicited corpus of spontaneous speech samples. We consider in particular the effects of the participants' cultural background (France vs. Maghreb), age and gender on the expression of prejudicial attitudes. Specifically, we tested in a context-sensitive sentiment analysis approach which attitudes (negative vs. positive) and emotions (joy, sadness, anger, fear, disgust) were voiced. We find strong effects of cultural background and gender both on the frequency of negative vs. positive attitudes expressed and on associated emotion categories, namely that male Maghrebian participants were more negative and conveyed more fear in their speech samples. The results are discussed in the context of current diversity approaches in France and their implications for potential prejudice regulation strategies.

keywords: sexual orientation prejudice, homonegativity, France

Sexual orientation prejudice (Herek, 2000; 2004) is increasingly common in Western societies and throughout the world, despite the fact that discrimination on the basis of perceived sexual orientation is considered wrong and that an increasing number of anti-discrimination laws have been adopted in order to protect members of the LGBTI (lesbian, gay, bisexual, transgender, or intersex) community (Mendos et al., 2020; Equality \& Human Right Commission, 2020). Moreover, the consequences of sexual orientation prejudice are severe: it can limit job opportunities (Fasoli, Maass, Paladino \& Sulpizio, 2017; Gowen \& Britt, 2006; Rule \& Alaei, 2016) and may impact adoption success (Fasoli \& Maass, 2020), sexual orientation prejudice can lead to discrimination in teaching contexts (Taylor \& Raadt, 2020) and may lead to an overall diminished quality of life and well-being (Blashill \& Powlishta, 2009; Jackson, Hackett, Grabovac, Smith, \& Steptoe, 2019; Lehavot \& Lambert, 2007; Miller, 2018).

Therefore, we are in need of explaining its underlying motivations more than ever before. Previous research has provided multiple explanations for sexual orientation prejudice. It might be, for example, motivated by previous unpleasant interactions with individuals happening to be homosexuals, i.e. negative interactions, which are subsequently 
overgeneralized and applied to all homosexuals (Herek, 2004). Or, sexual orientation prejudice has been explained by a mismatch between heterosexuals' norms and values, both on an individual level and a group level, and those of the gay community (van Leeuwen, Miton, Firat \& Boyer, 2016). And finally, homosexuals might be perceived as a threat to hegemonic masculinity by violating traditional gender roles (Blashill \& Powlishta, 2009; Glick, Gangl, Gibb, Klumpner \& Weinberg, 2007; Keiller, 2010; Lick \& Johnson, 2015; Parrott, 2009). Importantly, the latter can be regarded as culturally shaped by heteronormative belief systems that value masculinity or femininity differentially (Podesva et al., 2001; Valentova, Rieger, Havlicek, Linsenmeier \& Bailey, 2011).

Here, we focus on identifying anti-gay attitudes and their socio-cultural underpinnings in France. France is a multicultural society in which a large part of citizens has a recent migratory (Maghrebian) background (INSEE, 2021), and is influenced by different belief systems. These culture-differential belief systems and accompanying stereotypes can constitute a challenge for multicultural societies (Lankester \& Alexopoulous, 2020; Schiller et al., 2020; Verkuyten \& Yogeeswaran, 2020). The socio-cultural basis of sexual orientation prejudice in France, however, has largely remained unexplored, despite an overall alarming situation: SOS Homophobia's annual report, for instance, revealed an increase in the number of French hate crimes against members of the LGBTI community, which constitutes an increase for the forth consecutive year (Mendos et al., 2020).

The current study investigates, therefore, the socio-cultural underpinnings of sexual orientation prejudice in France in more detail. We consider in particular the effects of the social variables cultural background (France vs. Maghreb), age and gender on sexual stereotyping towards gays vs. lesbians. Specifically, we test whether sexual orientation prejudice in form of more negative or less positive attitudes and associated emotion categories (joy, sadness, fear, anger, disgust) towards male vs. female homosexuality/ homosexuals in France is motivated by these variables.

\section{Heteronormative belief systems, gender roles and sexual orientation prejudice}

In France and Maghreb, societies can be assumed to follow heteronormative belief systems. The latter, however, as well as linked gender norms of masculinity and femininity might differ and be differently endorsed across these countries (Al-Ghafari, 2002; Moussawi, 2011; Siraj, 2006).

Heteronormativity can be regarded as an institutionalized social force that proscribes appropriate and acceptable behaviours under the assumption that heterosexuality is normal (Habarth, 2015; Herek 2007; Kitzinger, 2014; Yep, 2003). Heteronormativity is closely 
related to gender role expectations, i.e. expectations of how men and women should behave, how they should express themselves or which interests they should have (Deaux \& Kite, 1987; Whitley, 2001). Typically men are expected to be "masculine”, i.e. strong and agentic, whereas expected "female" behaviours can be described as more passive and communal (Eagly \& Mladinic, 1989). Gender role expectations include also expectations about relationships and sexual behaviours, i.e. heterosexual relationships and behaviours in heteronormative societies (Habarth, 2015; Kitzinger, 2005). Therefore, heteronormative men, who have internalized heteronormativity to a high degree and thus intertwine sex and gender, feel they must engage with women in order to conform to societal norms and to be or appear sufficiently "masculine” (Herek, 1986; Kitzinger, 2005). A higher degree of endorsement of heteronormativity has been found to lead to an increase in negative attitudes towards homosexuality (Nagoshi et al., 2019; Whitley \& Ægisdóttir, 2000). In a system of social hierarchies, non-conformism with heteronormative ideals is associated with inferiority and lower status and leads to overall negative consequences (Deaux \& Kite, 1987; Gordon \& Meyer, 2007; Rudman \& Fairchild, 2004), especially for men (Sirin, McCreary \& Mahalik, 2004; Vandello, Bosson, Cohen, Burnaford, \& Weaver, 2008). This is true because social hierarchies benefit the dominant who want to maintain their dominance (Herek 2016; Jost \& Banaji, 1994; Pratto et al., 2006). If their dominance or masculine characteristics are threatened or perceived as threatened by non-conform behaviour (Herek, 1986; Kiss et al., 2018; Parrott, 2009; Parrott \& Zeichner, 2008; Theodore \& Basow, 2000; Whitley and Ægisdóttir, 2000), heteronormative ideology leads then to anti-gay attitudes or negative emotions (e.g., disgust; Ray \& Parkhill, 2021), sometimes even avoidance behaviour (e.g., fear; Bosson et al., 2006; Bosson et al., 2011; Buck et al., 2013), in the observers (Nagoshi et al., 2019), aiming at differentiating oneself from the violator of heteronormativity (Bosson et al., 2011; Herek, 2016; Parrott, 2009; Parrott \& Zeichner, 2008). In this context, emotions can be regarded as adaptive mechanisms that produce specific cognitive, physiological and behavioural responses to challenging, i.e. (perceived as) threatening, environmental stimuli (Damasio, 1994; Schwarz \& Clore, 1996), and are therefore crucial for intergroup relations. Joy (or happiness), for instance, can point at satisfaction, sadness can signal personal loss and the need for caution (Bodenhausen et al., 1994). Anger has been found to signal the need for approach and rapid action, and has been discussed in the context of aggressive homophobia (van Leeuwen et al., 2016). Fear has been investigated as anxiety and avoidance response to imagined, anticipated, and actual contact with a lesbian or gay individual (Buck et al., 2013). Disgust has been found to be an emotional response to contagious, offensive, distasteful, or 
unpleasant environmental stimuli and has lately been investigated in the context of intergroup relations, in particular as heterosexual men’s response to gay men (Ray \& Parkhill, 2021).

\section{Sexual orientation prejudice across cultural contexts}

Heteronormative belief systems and norms of masculinity and femininity are grounded in specific cultural contexts and might vary accordingly (Podesva, Roberts \& Campbell-Kibler, 2001; Valentova \& Havliček, 2013). Recent large-scale and longitudinal studies into attitudes towards homosexuality suggest that sexual orientation prejudice is culturally shaped (Inglehart et al., 2014; OCDE, 2019). Moreover, the cultural belief-systems are closely related to religious affiliations and religiosity (Bochow, 2003; Glick et al. 2007; Keiller, 2010; McDermott, Schwartz, Lindley \& Proietti, 2013; Reese, Steffens \& Jonas, 2014]; SakallıUğurlu \& Uğurlu, 2016; Simon, 2008). Religion has been found to be a strong predictor of sexual orientation prejudice. Anderson \& Koc (2015), for instance reveal a strong link between Islam (vs. Atheism) and explicit anti-gay attitudes, especially towards gay men. Moreover, sexual stereotyping has been generally found to be more frequent in Muslimmajority countries (Jäckle \& Wenzelburger, 2015; Smith et al., 2014;) where homosexuality is often rejected for religious reasons (Adamczyk \& Pitt, 2009; Kligerman, 2007; Sherkat et al., 2011; Scull \& Mousa, 2017).

\section{Age and sexual orientation prejudice}

Sexual stereotyping is most certainly not only varying across cultures, but also across different age groups. Sexual stereotyping is generally assumed to be higher in older populations, homosexuality being more accepted among the youth (OECD, 2019). This has been explained by an "ageing effect”, i.e. the fact that people become less accepting towards homosexuality when they grow older. Recent studies, however, suggest a cohort effect whereby younger generations are more liberal, and therefore more conducive to greater acceptance of sexual minorities. The within-cohort study by Andersen \& Fetner (2008), for instance, analyses the tolerance of homosexuality in Canada and the United States, using a dataset from the World Values Survey (1981-2000). The study reveals younger cohorts as being typically the most tolerant; the researchers also find proof for improvements in acceptance of homosexuality over time within all cohorts, hereby refuting the age-stability hypothesis that claims that opinions on controversial social issues are formed by early adulthood, and change little with age.

By contrast, a recent study on anti-gay prejudice in Jamaica finds that especially young men (with lower income and less education) report more anti-gay behaviour than women (Borras 
Guevara \& West, 2020). Another study, conducted in non-Western populations, the three Asian cities Hanoi (Vietnam), Taipei (Taiwan) and Shanghai (China), identified mainly negative perceptions of homosexuality in young adults. Their homonegativity was explained by a lack of knowledge with respect to sexual and reproductive health as well as by traditional values influenced by Confucianism (Feng et al., 2012).

Overall, these results suggest that sexual stereotyping is less frequent in younger Westerners than in older age groups. However, this might not be true for non-Western countries due to different cultural belief systems where sexual orientation prejudice is also high in younger populations. Additionally other factors such as socio-economic status or education might modulate the degree of homonegativity in younger age groups. If sexual orientation prejudice in France is lower in younger people of French vs. Maghrebian background has not yet been sufficiently explored.

\section{Gender and sexual orientation prejudice}

Closely related to heteronormative belief systems that mainly refer to norms of masculinity is the finding that sexual orientation prejudice is stronger in men. Studies consistently find that in Western societies, in the United States (Davies, 2004; Poteat \& Anderson, 2012; Whitley, 2001, 2009) and in Europe (Ciocca et al., 2017; Lingiardi, Falanga, \& D’Augelli, 2005; van den Akker, van der Ploeg, \& Scheepers, 2013), for instance, men (vs. women) report more anti-gay attitudes. This is also supported by some cross-cultural investigations of sexual orientation prejudice (Adamczyk \& Pitt, 2009). However, if the association of sexual orientation prejudice and gender varies as a function of culture remained largely unexplored. By contrast, some studies suggest that the finding of men being more negative towards homosexuality is not generalizable to non-Western societies (Feng et al., 2012; Proulx, 1997). Moreover, a recent large-scale investigation on attitudes towards gays and lesbians across overall 23 Western and non-Western countries suggests that the relationship between participant gender and sexual stereotyping is inconsistent in Western countries, but not in nonWestern countries, where men (vs. women) hold more negative attitudes against gays (Bettinsoli, Suppes \& Napier, 2019). The impact of cultural belief systems on sexual stereotyping in multicultural societies such as France has not yet been investigated.

\section{Sexual orientation prejudice toward gay men vs. lesbian women}

Due to hegemonic masculinity, men hold more negative attitudes towards homosexuals, but they are also more often victims of sexual stereotyping. At least in Italy and the United States attitudes towards gays are more negative than towards females (Herek, 2002, Whitley, 2001; 
Pistella et al., 2018). Overall, men report more negative attitudes towards gays (vs. lesbians) than females, the latter not differentiating between the type of homosexuality (Herek, 2000, 2002; LaMar\&Kite, 1998, Span \& Vidal, 2003; but Proulx, 1997). Whether sexual orientation prejudice in French citizens towards gays (vs. lesbians) is higher in men than women has not yet been investigated. Moreover, it remains largely unclear whether differences in sexual orientation prejudice towards gay vs. lesbians hold cross-culturally, and in particular across French citizens with French vs. Maghrebian cultural background. So far, investigations with a cross-cultural focus have mostly neglected to specify the type of homosexuality, the target items only asking respondents to report their views on "homosexuals" or "homosexuality" which is very likely understood as targeting male homosexuality (Herek, 2002; Kite \& Whitley, 1998; but Bettinsoli, Suppes \& Napier, 2019).

\section{Sexual stereotyping and sentiment analysis}

In order to investigate the socio-cultural basis of sexual orientation prejudice in form of negative attitudes towards homosexuality/ homosexuals in France, we apply sentiment analysis techniques to our corpus of experimentally elicited speech samples. Sentiment analysis is the automatic determination of emotion in text, comprising valence (i.e., positivity, negativity or neutrality), emotions (e.g., anger, joy, disgust), and other affectual states, using computer algorithms (Mohammad, 2021). More generally, sentiment analysis can determine one’s attitude towards a particular target or topic, i.e. one’s evaluative judgment (positive/ negative), one's affectual attitude (e.g., frustration, anger, etc.) or one's emotional state (Mohammad, 2021).

This approach is specially suited in order to explore our data and in particular the sociocultural basis of sexual orientation prejudice in France. Sentiment analysis has been successfully applied before in studies aiming at a better understanding of social groups which focussed, for instance, on differences in emotions in language used by different social groups or on differences in language mentioning people from diverse backgrounds (Grijalva et al., 2014; Mohammad \& Yang, 2011; Montero, Munezero, \& Kakkonen, 2014).

However, sentiment analysis comes with some challenges. The most important challenge is that language in use is complex and subtle, i.e. the meaning of a sentence or text (utterance meaning or pragmatic meaning) is not just simply the sum of the meanings of its parts (word or lexical meaning; Mohammad, 2021). Moreover, language can be used creatively and in non-standard ways (Mohammad, 2021). To provide one specific example from our dataset, homosexuality or homosexual is not simply a negative lexical item, as is assumed by default in common affect lexicons, but can be positively or negatively construed in context (e.g., 
homosexuals as friends), or lexical items might be modified, i.e. negated, amplified or intensified (e.g., I am not disgusted/very disgusted). These challenges can, however, be met by using algorithms that have been trained on a sufficiently large and high-quality dataset, or by manual analyses. While automatic analyses are error prone, manual analyses are costly and time-consuming (Abdaoui, Azé \& Bringay, 2017). Another challenge for the analysis of the French dataset is that work on sentiment analysis in languages other than English are rare, and therefore, less accurate (Abdaoui, Azé \& Bringay, 2017). However recently, there has been an increasing interest in French sentiment analysis and efforts to leverage the resources available in English for sentiment analysis in French and other resource-poor languages (Kooli \& Pigneul, 2018; Paroubek et al., 2018; Tapi Nzali et al., 2017).

In our approach, we combine automatic with context-sensitive manual analyses, and therefore, resolve the challenges outlined above. Moreover, our analysis yields a French affect lexicon on 'homosexuality' that might be applied or extended for future research.

\section{The current research}

Using a corpus of experimentally elicited, spontaneous speech samples by French participants of differing cultural background, age and gender, we investigate the socio-cultural underpinnings of sexual orientation prejudice towards gays vs. lesbians. Specifically, we test whether sexual orientation prejudice in France in form of positive vs. negative sentiments and emotions towards homosexuality/ homosexuals is dependent on the cultural background, on age, on the gender, and the type of homosexuality (male vs. female homosexuality). Hereby, we specifically differentiate between negative attitudes towards gays vs. lesbians, which has been largely neglected (but cf. Bettinsoli, Suppes \& Napier, 2019) by questionnary-based investigations which do not define the type of 'homosexuality'. Moreover, our experimental design targets attitudes towards homosexuality implicitly, via photo prompts, and avoids therefore to a certain degree that the participants are not straightforward.

Based on previous research outlined above, we hypothesize that French Maghrebians may exhibit stronger stereotypical behaviours, i.e. be more negative and use affect lexis associated with anger, fear or disgust (Hypothesis I). Moreover, younger people should be less prejudiced towards gays and lesbians, therefore more positive and use affect lexis associated with joy (Hypothesis II). Following heteronormative ideology and the related masculinity threat hypothesis, males should be more prone to sexual orientation prejudice than females, therefore use more negative items and affect lexis conveying anger, fear or disgust (Hypothesis III), and finally male homosexuality should be less accepted than female 
homosexuality (Hypothesis IV), and therefore lead to more negative sentiments and conveyed anger, fear or disgust.

\section{Methods}

\section{Participants}

We recruited study participants by means of advertisements in the city of Montpellier, France. All participants gave written consent prior to the study and were given a financial compensation for their participation. In total, 148 women and 181 men provided speech samples (Median $(M)=25$, Interquartile Range $(I Q R)=22-29)$ and completed a questionnaire assessing their sexual orientation (i.e., they had to state whether they considered themselves as being homosexual, heterosexual, bisexual, or other), nationality, age, as well as country of birth of their parents and grandparents. The French National Commission on Informatics and Liberty approved all protocols used in this study (CNIL Number 2-17029\UMR5554).

\section{Procedure \& measures}

The participants were randomly presented with one of eight pictures evoking homosexuality. Half of the pictures showed two males, the other half two females intimately involved (e.g., french-kissing). Each participant was asked to describe freely what the picture evoked to them without prior knowledge of the study aim. Subsequently, the data was manually transcribed. Data analysis was performed on a subset of the speech samples wedding sentiment analysis and discourse analytical procedures. This complementary approach allowed us to retrieve subjective information with respect to homosexuality and to perform a context-sensitive analysis, e.g., to retrieve negative and positive polarity items (word-level polarity) conveying negative or positive meaning in their linguistic context (sentence-level polarity). The subsample analysed comprised speech samples of heterosexual participants of French and Maghrebian origin (cf. Table 1). Maghrebian origin was defined as having at least one Maghrebian, i.e. Algerian, Tunisian or Moroccan, parent or grand-parent.

Table 1. Descriptive statistics - corpus size and sociocultural variables. 'N' stands for 'number', 'M' stands for 'median', 'IQR' stands for 'interquartile range' in '()'.

\section{French}

\section{Maghrebian}

participants $\mathbf{N}$ (total)

\section{female}

lexical tokens $\mathbf{N}$ (raw frequencies)

age (M and IQR)
54

5767

(22) 23 (28) male

25

3501

(22) $23(32)$

\section{female}

44

5480

(21) 24 (26) male 50

6680 
Sentiment analysis

\section{Polarity lexicon}

In order to perform a polarity analysis of the data, an association lexicon was created in a corpus-driven approach. The creation of the association lexicon was facilitated by the webbased annotation tool Webanno, provided within the CLARIN-EU infrastructure (Eckart de Castilho et al., 2016; Yimam et al., 2014). This annotation tool allows custom-layer annotations and the export of the annotated data files which enables subsequent data exploration and statistical analysis.

Lexical items in the corpus that had a core positive (e.g., bien, 'good') or negative (e.g., mal, 'bad') meaning (i.e., denotation) or were closely associated with positive (e.g., libre, 'free') or negative (e.g., péché, 'sin’) valence (i.e. connotation) were included in the lexicon. Hereby, word-level valence (lexical meaning) was established in context. That means that the linguistic context (utterance meaning) of the words was taken into account in order to decide whether an item was positive or negative (i.e., pragmatic meaning). This included taking negations into account, since negation can change the truth value of the proposition. After identification of the negation, the polarity of the items under the scope of negation, that is, those affected by the negation word, were changed to the appropriate polarity: a negated positive item was not counted as positive, but negative (e.g., c'est [l'homosexualité] pas naturel, 'this is not natural'); and a negated negative item was not counted as negative, but neither as positive (e.g., je ne suis pas contre [l'homosexualité], 'I am not against [homosexuality]'). Degree modifiers (e.g., un peu, 'slightly'), intensifiers (e.g., très, 'very') or modals (e.g., peut, pourrait, 'can, could') have not been taken into account, since they do not change the propositional value of the utterances, which we wanted to determine in this approach, but modify its emotionality, i.e., the degree of the overall sentiment. We neither focused specifically on figurative language, sarcasm/ irony or metaphor.

Overall, we were interested in the speaker's positive and negative sentiments towards homosexuality, and we included in these categories both utterances that expressed first-person sentiment ([...] je suis dégôuté, 'I am disgusted') and third-person sentiment e.g., c’est [l'homosexualité] parfois très mal vu, voir condamné à mort, 'it [homosexuality] is sometimes very poorly looked upon, even condemned to death'). Therefore, also utterances were included that evoked positive or negative events or descriptions, and strictly speaking, not speaker's sentiment. Despite this, we included third-person sentiment, since we found that it substantially contributes to the way in which homosexuality was positively or negatively construed, i.e. perceived and experienced by the participants. 
We also distinguished in our analysis between different parts-of-speech (POS), focussing separately on nouns, verbs and adjectives/ adverbs, that were associated with positive or negative sentiment. The reason for this is that these POS can realize positive or negative sentiment differentially (Fronhofer, 2020), which became also clear from a preceding qualitative analysis of the corpus: nouns primarily refer to the ways in which homosexuals are addressed (e.g., pédé, 'faggot'), provide reasons for the negative or positive sentiment (e.g., crime, 'crime'), and describe positive or negative events (e.g., manifestations, 'demonstrations'); the category of verbs mainly subsumes positive or negative sentiments in form of actions towards homosexuals (e.g., insulter, 'to insult' or tolérer, 'tolerate') or constitutes first-person sentiments (e.g., ça me dégoûte, 'it disgusts me’, j’accepte, 'I accept'); and finally the category of adjectives/ adverbs puts together evaluative attributes of homosexuals' orientation (e.g., normal, 'normal' or malade, 'ill').

\section{Conveyed emotions}

In order to analyse the conveyed emotions joy, sadness, fear, anger and disgust of the corpus, we performed an automatic, dictionary-based sentiment analysis using a tidy text mining approach (Silge \& Robinson 2017). As dictionary and for emotion classification we used the FEEL lexicon (Abdaoui, Azé \& Bringay, 2017), which is one of the rare dictionaries for French sentiment categories that exist, and which obtained competitive results, especially for emotion classification. Moreover, FEEL was compiled combining automatic translation with human professional translation, i.e. the French lexicon was automatically translated departing from the English English NRC Word Emotion Association Lexicon (NRC-EmoLex; Mohammad \& Turney 2013) and was subsequently validated by a human translator. A subset of the classifications were subject to further evaluations by three different annotators to assure consistency. For our analysis of conveyed emotions in the corpus we screened the manually created affect lexicon for the associated emotion categories joy, sadness, fear, anger and disgust. In order to perform this analysis, we used the inner join function (Silge \& Robinson 2017). Subsequently, the emotion categorizations were controlled and miscategorizations due to contextual effects, i.e. negations, for instance, have been corrected and the corresponding emotion category has been assigned manually.

\section{Statistical analysis}

All statistical analyses were performed using R (version 4.0.5; R Development Core Team 2021) and binomial GLMMs ('Ime4’ package version 1.1-27; Bates et al., 2021; Levshina, 2015). This allowed us to analyse the number of negative and positive polarity items 
(separately for adjectives, verbs and nouns) relative to the total number of words per speech sample as response variable, using cultural background, sex, the interaction of cultural background and sex, age, and the sex of the kissing couples on the picture prompts as explanatory variables. An observation-level-random effect was included in order to account for overdispersion. For the analysis of conveyed emotions, we calculated the number of affect lexemes per emotion category (joy, sadness, fear, anger, disgust) relative to the total number of affect lexemes per speech sample as response variable, using emotion category, gender and cultural background, as well as the interactions between cultural background and sex, emotion category and sex as well as emotion category and cultural background as explanatory variables. We excluded the variables of age and photo gender in the analysis of conveyed emotions, since these variables had shown no or weak effects in the polarity analysis. A participant-level random effect was included here in order to take into account that one study participant could contribute emotion lexemes to different categories.

In both analyses we used model selection based on AICcs ('MuMIn' package version 1.43.17). We report the top ranked models (within $2 \Delta$ AICc values of the best ranked model) as well as relative parameter importances (sums of AICc weights) and show averaged model predictions (AICc weight-based prediction averaging) for these models.

\section{Results}

\section{Negative polarity}

Focusing on the negative polarity items in our final sub-corpus, our AICc-based model selection analysis reveals an overwhelmingly strong effect of cultural background (relative importance, RI = 1), whereby study participants with Maghrebian background consistently used more negative lexical items across all POS, i.e. more negative adjectives, nouns and verbs (Fig. 1, Table 2), than participants with French background. Participant gender modulated the effect of cultural background, especially for nouns which becomes evident from the background $\mathrm{x}$ gender interaction retained by model selection (Table 2B): females with French background exhibited relatively more negative nouns than males with French background, while this difference was inverted for participants with Maghrebian background (Fig. 1B; Table 2B). Moreover, gender was also retained in the top model for verbs, females using more negative verbs than males (Fig. 1C; Table 2C). Finally, participant age (parameter: age; Fig 1; Table 2) and gender of the homosexual couples shown in the picture prompts (parameter: photo gender) had overall only weak additive effects. 


\section{Positive polarity}

The AICc-based model selection analysis of positive polarity items in the final sub-corpus confirms the strong effect of cultural background ( $\mathrm{RI}=0.94$ for adjectives, $\mathrm{RI}=0.84$ for nouns, but not for verbs, RI=0.27; Fig. 2, Table 3) observed with respect to negative polarity. Participants of French background used more positive adjectives and nouns than participants with Maghrebian background, while no difference was observed for verbs. Moreover, model selection revealed a consistent effect of age $(\mathrm{RI}=0.46, \mathrm{RI}=0.70$ and $\mathrm{RI}=0.95$ for adjectives, nouns and verbs respectively; Fig. 2), older participants using more positive polarity items across all POS independent of cultural background. In contrast to negative polarity items the analyses was overall less conclusive and the effects of other explanatory variables was weak or inconsistent as becomes clear from the low weights associated with the top models (Table 3) and the large confidence intervals (Fig. 2).

\section{Context-sensitive qualitative analysis of the polarity lexicon}

The qualitative analysis of the polarity lexicon in context (cf. Appendix, Tables 1-4) corroborates the results obtained in the quantitative polarity analysis. Focusing on negative polarity items, we find that the negative lexical items differ qualitatively across participants of Maghrebian and French background: the lexical items Maghrebian participants use with respect to homosexuality or homosexuals are more negatively loaded. Examples comprise the nouns maladie ('illness') or péché ('sin'), the adjectives bizarre ('bizarre’), pas normale ('not normal'), rare ('rare') or the verbs/ verbal phrases ça me dégoûte ('it [homosexuality] disgusts me'), je ne comprends pas ('I don’t understand'), je déteste ('I hate') and j'évite au maximum ('I avoid the most possible [homosexuals/ homosexuality]'). By contrast, the French participants' negative nouns, adjectives and verbs mostly describe negative events (une exposition qui a été détruite, 'an exposition that has been destroyed') and difficulties homosexuals are confronted with (e.g., c'est difficile 'it is difficult', ils sont persécutés, 'they are persecuted'). 


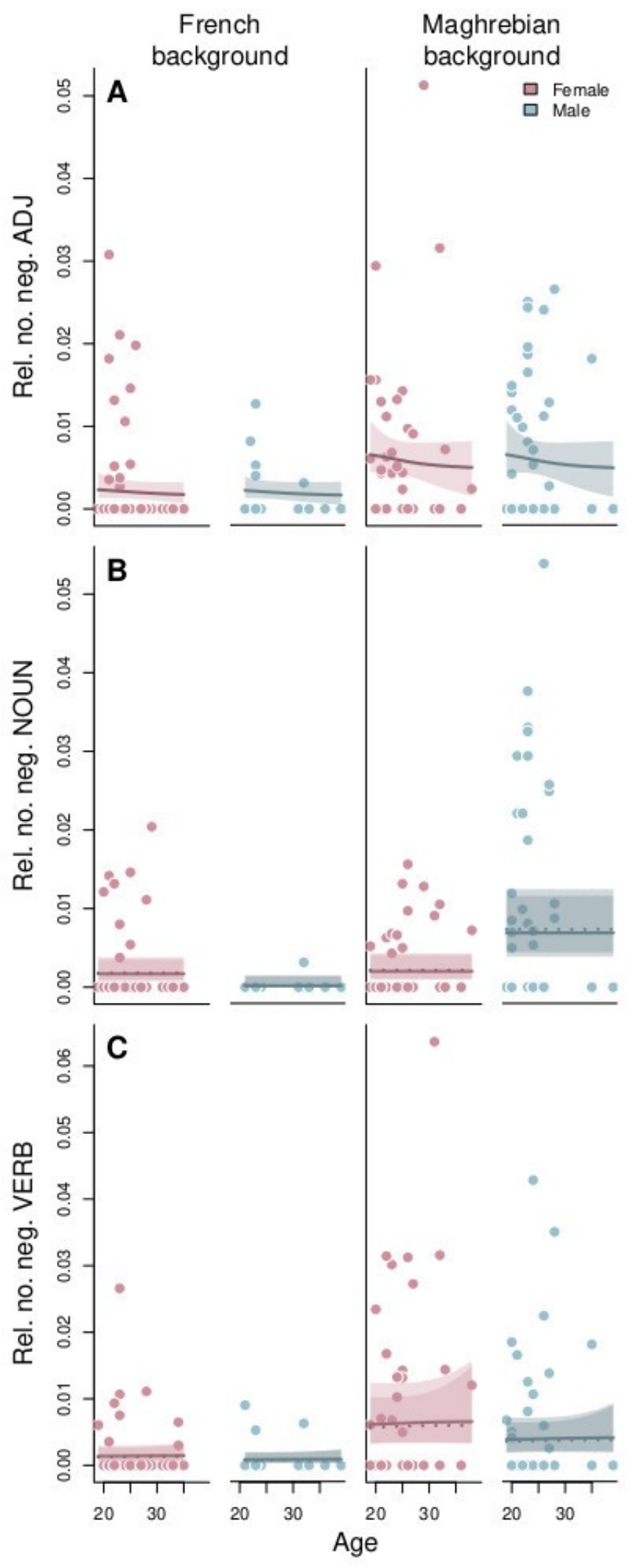

Figure 1: Relative frequencies (occurrence/ total words per text) of negative adjectives (A), nouns (B) and verbs (C) for participants of different age with French and Maghrebian background as well as females (pink) and males (blue). Full dots show data points. Solid lines visualize AICc-based averaged model predictions (prediction averaging based on AICc-weights) and shaded areas the 95\% confidence intervals. When the parameter photo gender was retained in the best models selected (models with $\Delta \mathrm{AICc}<2$, cf. Table 2), solid lines show the model prediction for observing female photo gender, dotted lines visualize the model prediction for observing male photo gender. 
Figure 2: Relative frequencies (occurrence/ total words per text) of positive adjectives (A), nouns (B) and verbs (C) for participants of different age with French and Maghrebian background as well as females (pink) and males (blue). Full dots show data points. Solid lines visualize AICc-based averaged model predictions (prediction averaging based on AICc-weights) and shaded areas the 95\% confidence intervals. When the parameter photo gender was retained in the best models selected (models with $\Delta \mathrm{AICc}<2$, cf. Table 3), solid lines show the model prediction for observing female photo gender, dotted lines visualize the model prediction for observing male photo gender. 


\section{Model}

background + gender

background + gender + photo gender background

background + age + gender

\section{B. NOUN - model selection table}

\section{Model}

background $\mathrm{x}$ gender

background $\mathrm{x}$ gender + photo gender

$\begin{array}{lc}\text { Parameter } & \text { RI } \\ \text { background } & 1 \\ \text { gender } & 1 \\ \text { background x gender } & 0.99 \\ \text { photo gender } & 0.31 \\ \text { age } & 0.25\end{array}$

\section{I}

$d f$

4

3

RI

1

0.51

0.36

0.26

0.14 $d f$

5

6 $\triangle A I C c$

0

0.11

$W_{\text {AICC }}$

0.24

0.23

574

Parameter RI

background 1

gender $\quad 0.73$

photo gender $\quad 0.38$

age $\quad 0.31$

background x gender $\quad 0.19$

$\triangle A I C c$

$W_{\text {AICC }}$

0.00

0.52

1.60

0.23

.


Table 3: AICc-based model selection results for positive adjectives, nouns and verbs. We only show results for 585 the models with $\triangle$ AICc $<2$ in detail.

\section{A. ADJ - model selection table}

Model

background

background + age

background + gender

background + gender + age

$\triangle A I C C$

\section{0}

0.33

0.39

0.70

1.72
$W_{\text {AICC }}$

0.17

0.15

0.14

0.12

0.07

590

$\begin{array}{lc}\text { Parameter } & \text { RI } \\ \text { background } & 0.94 \\ \text { gender } & 0.52 \\ \text { age } & 0.46 \\ \text { photo gender } & 0.28 \\ \text { background x gender } & 0.12\end{array}$

\section{B. NOUN - model selection table}

\section{Model}

background $\mathrm{x}$ gender + age

background + age

background $\mathrm{x}$ gender

6

4

Parameter RI

background $\quad 0.84$

age $\quad 0.70$

gender $\quad 0.62$

background $\mathrm{x}$ gender $\quad 0.39$

photo gender 0.26

\section{VERB - model selection table}

Model

age + photo gender

age

age + gender + photo gender df

4

3

5

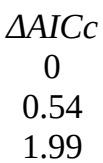

$W_{\text {AICC }}$

0.29

0.22

0.11

600

$\begin{array}{lc}\text { Parameter } & \text { RI } \\ \text { age } & 0.95 \\ \text { photo gender } & 0.57 \\ \text { gender } & 0.28 \\ \text { background } & 0.27 \\ \text { background x gender } & 0.02\end{array}$




\section{Conveyed emotions}

Focusing on the frequencies of discrete emotion categories joy, sadness, fear, anger and disgust present in the extracted affect lexicon, our analysis reveals a strong effect of emotion category and cultural background as well as an interaction between emotion category and cultural background (RI = 1; Table 4). Overall, joy was the most prevalent emotion category, sadness, anger, fear and disgust being less frequent (Fig. 3). Moreover, the affect lexemes were differentially distributed across cultural backgrounds, participants with Maghrebian background using less joy lexemes, but more fear lexemes. This mirrors the high number of negative items in the Maghrebian speech sample identified in the polarity analysis and suggests that the negativity is mainly driven by the emotion category fear, and less by anger and disgust. The results also reflect the high number of positive polarity items in the French speech samples, positivity being due to the conveyed emotion joy. Gender and the emotion category $x$ gender interaction, as retained by the second best model $(\mathrm{RI}=0.64, \mathrm{RI}=0.46$; Table 4), potentially point at a tendency of males conveying less joy, and more fear, anger and disgust instead.

Table 4: AICc-based model selection results for JOY, SADNESS, FEAR, ANGER, DISGUST lexemes (relative to the total number of affect lexemes). We show results for the two top model, $\Delta$ AICc $<2$, in detail.

\section{Conveyed Emotions - model selection table}

\section{Model}

emotion category $\mathrm{x}$ background emotion category $\mathrm{x}$ background + emotion category $\mathrm{x}$ gender

$\begin{array}{lc}\text { Parameter } & \text { RI } \\ \text { emotion category } & 1 \\ \text { background } & 1 \\ \text { emotion category x } & 1 \\ \text { background } & \\ \text { gender } & 0.64 \\ \text { emotion category x } & 0.46 \\ \text { gender } & \\ \text { background x gender } & 0.17\end{array}$

$\begin{array}{cc}\triangle A I C C & W_{\text {AICC }} \\ 0.00 & 0.36 \\ 0.10 & 0.34\end{array}$

0.36
0.34 

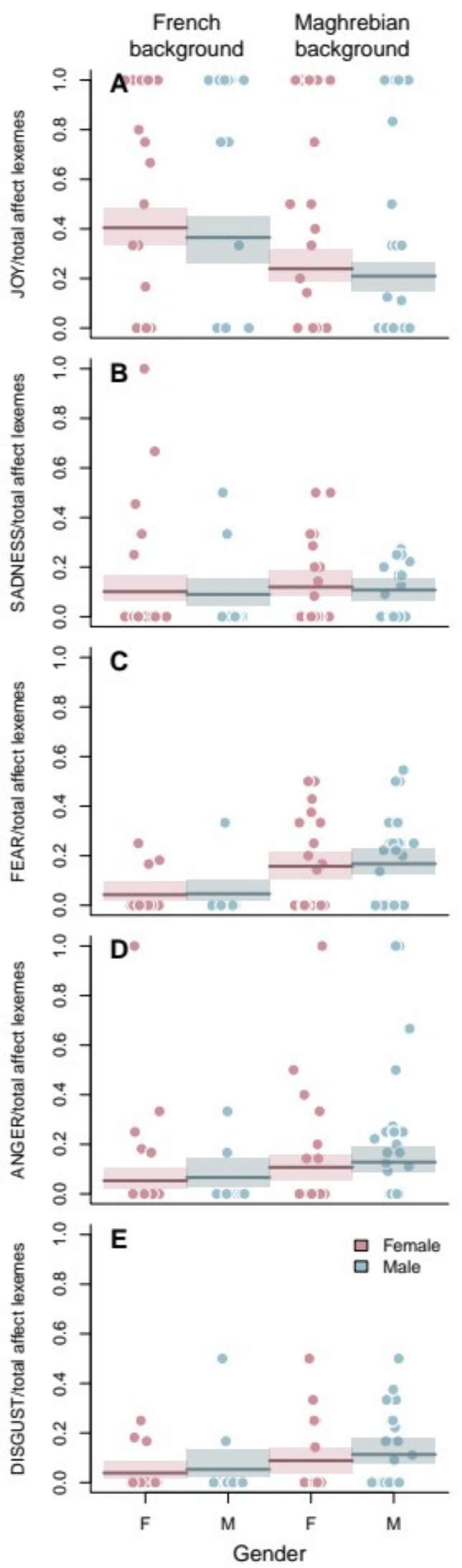

Figure 3: Relative frequencies (discrete affect lexeme/ total affect lexemes per text) of emotion categories joy (A), sadness (B), fear (C), anger (D), disgust (E) for female (pink) and male (blue) participants with French and Maghrebian background. Full dots show data points. Solid lines visualize AICc-based averaged model predictions (prediction averaging based on AICc-weights) and shaded areas the 95\% confidence intervals (models with $\triangle \mathrm{AICc}<2$, cf. Table 4). 


\section{General discussion}

Our analysis of sexual orientation prejudice in France (towards male vs. female homosexuals) in form of positive and negative sentiments and conveyed emotions in speech samples of French participants with varying cultural background (French vs. Maghreb), age and gender yielded two main findings: Cultural background and gender drive sexual stereotyping in France.

\section{Cultural background modulates the expression of sexual stereotypes}

Our analysis yielded a strong effect of cultural background on the frequency of negative (all POS) and positive (for adjectives and nouns) items, suggesting that participants of Maghrebian background were more negative and less positive towards homosexuality/ homosexuals. This is also reflected in the analysis of emotion categories, participants with Maghrebian background conveying less joy, but more often fear. This validates our first hypothesis that French Maghrebians may exhibit stronger stereotypical behaviours. Moreover, it supports the general finding that suggests that sexual orientation prejudice is culturally shaped.

However, these results have to be interpreted with caution. First of all, it would be interesting to look more closely at what exactly motivated the negativity or positivity, and joy vs. in particular fear in the present speech samples, i.e. what "makes" the specific cultural beliefsystems that are at play, and which specific causes or justifications the participants provide for the positive or negative attitudes they voice, and the emotions that are conveyed. Moreover, from a linguistic point of view, it would be interesting to know whether changing our approach of conceptualizing and analysing first-person negativity and third person negativity as one category, as is a viable approach in sentiment analysis, might substantially alter our results. Also, as the qualitative results suggest, it would be interesting to consider the overall emotionality of the speech samples across the cultural backgrounds, i.e. the intensity of the negativity, from a quantitative point of view.

More important, however, than identifying potential causes of operating cultural beliefsystems in France might be to underline the fact that the diversity in belief systems creates important challenges for multicultural societies, and sexual stereotyping is but one example. So, the question of how to successfully cope with diversity on a societal level, crucial for fostering harmonious intergroup relations, remains to be tackled. As recent research highlights, the recognition of diversity in France was and still is a delicate issue (Bertossi, 2016; Simon, 2013) as differences are still being contested and create deep-rooted anxieties about cultural differences (Schiller, 2020). So, it can be assumed that diversity in France is 
not efficiently addressed. Currently, two distinct norms of Laïcité in France, egalitarian Historic Laïcité and assimilationist New Laïcité, are used as sociopolitical tools to handle diversity (Lankester \& Alexopoulous, 2021). The latter, assimilationist norm has been traditionally associated with cognitive regulation processes that lead to higher levels of prejudice in comparison to the egalitarian norm. However, recent findings suggest that this is not so straightforward (Lankester \& Alexopoulous, 2021). The authors hypothesize that "the desire to appear non-prejudiced drives the suppression of prejudice within the realm of the egalitarian Historic Laïcité norm", and vice versa, "the desire to release the pressure stemming from a relentless commitment to egalitarianism encourages the justification of prejudice within the realm of the assimilationist New Laïcité context” (Lankester \& Alexopoulous, 2021: 9). In order to efficiently reduce prejudice the authors propose to reframe the Historic Laïcité norm as an "identity-conscious” norm and to adopt an approach to diversity (e.g., Leslie et al., 2020), in which similarities and differences with out-groups are highlighted, and which ultimately leads to effective prejudice regulation via perspectivetaking, i.e. the active attempt to embrace and identify with the experience of other individuals (Todd \& Galinsky, 2012).

\section{Gender modulates the expression of sexual stereotypes}

Our results showed that gender modulated the cultural background effect with respect to negative nouns, the French females and the Maghrebian males using more negative nouns than their counterparts. Moreover, females used more negative verbs than males. Gender and the emotion category $\mathrm{x}$ gender interaction played also a role in the analysis of conveyed emotions and was retained in the second best model. This only partly validates the masculinity threat hypothesis (Hypothesis III) that men should be more prejudiced towards gays and lesbians than females, and our findings are only to a certain degree consistent with previous research.

However, the higher negativity in French females might be due to the fact that we coded firstperson and third-person negativity together in one category. A qualitative analysis of the affect lexicon shows that negative nouns (e.g., manifestation, 'demonstration' or victime 'victim') used by the French females often describe negative events or comment on the negative situation homosexuals might find themselves in. This is by contrast not true for the nouns often used by Maghrebian males who consider homosexuality for examples as illness (e.g., maladie).

Moreover, it has to be noted that we do not observe inconsistencies of the kind Bettinsoli,

Suppes and Napier (2019) report. Across nations, the researchers observe gender effects, the 
males being more negative towards gay men, but not towards lesbian women, and they find on a country-level that French men are more negative towards lesbians.

\section{Limitations and directions for future research}

Does age modulate the expression of sexual stereotypes?

At least in most Western societies, younger age groups have been found to accept homosexuality more, and therefore, we hypothesized (Hypothesis II) that participants of younger age in our sample should be less prejudiced towards gays and lesbians. Unexpectedly, we found only weak age effects with respect to negative polarity and conveyed emotions, but a strong age effect for positive polarity, older participants using more positive items than younger participants, and therefore pointing at less homonegativity.

The weak age effect (for negative polarity and conveyed emotions) might be due to the fact that the study was not originally designed to investigate sexual orientation prejudice across different age groups, and therefore, the number of participants per each age group might not be sufficient in order to be conclusive. The age effect with respect to positive polarity, a higher number of positive items was used by older participants, might be explained by agerelated changes in motivation that direct behaviour and cognitive processing, in particular by the positivity effect (e.g., Carstensen \& DeLiema, 2017). This effect states that older adults (vs. younger adults) attend to, remember and prefer positive information more than negative information. From an evolutionary point of view, it has been hypothesized that postreproductive members of groups who are emotionally stable focus their attention more on positive information, which ultimately benefits the larger group (Carstensen \& DeLiema, 2017). However, as we have stated above, this remains a hypothesis due to the overall sampling in the study and overall age distribution. Alternatively, it might also be that people of (slightly) older age do perceive non-heteronormative behaviours, such as homosexuality represented by our picture prompts, less as a threat to their masculinity, having reached an age of maturity, while younger people, still in search for their identity, might still have to assert it. Overall, our results are, however, non-conclusive with respect to the effects of age on sexual stereotyping, and future cross-generational studies tailored to this question are needed in order to shed more light onto this issue. They should also take further variables such as education or socio-economic background into account.

Are sexual stereotypes stronger toward gays vs. lesbians?

From our analysis of sentiments and conveyed emotions we cannot conclude that sexual stereotypes are stronger towards gays vs. lesbians (Hypothesis IV), as the effects of the 
picture prompts (male vs. female homosexuality) were overall only weak. Therefore, we cannot validate our fourth hypothesis predicting that male homosexuality should be less accepted. Recent cross-cultural research (e.g., Bettinsoli, Suppes \& Napier, 2019), however, has corroborated previous findings for the US (e.g., Herek, 2000) or Italy (e.g., Pistella et al., 2018) that gays are disliked more than lesbians. So, either this is not true for French gays vs. French lesbians, or our study failed to detect this effect. As we did not ask explicitly about female vs. male homosexuality, it might be that the picture prompts left too much room for interpretation. Alternatively, male and female homosexuality in France is liked or disliked in the same ways, pointing perhaps at an increasing acceptance of both gays and lesbians who publicly assume their sexuality.

\section{General conclusion}

Although much research has examined the multiple reasons for sexual stereotyping, the sociocultural basis of sexual orientation prejudice in France has remained largely unexplored. However, findings might provide novel insights into drivers and motivations of sexual stereotyping and might ultimately help mitigate or prevent sexual orientation prejudice in multicultural societies. One way of doing this might be to actively embrace diversity, to responsibly raise awareness of both similarities and differences within and between groups, and to valorize them, in order to create a climate conducive to taking others' perspectives.

As so few is known about the socio-cultural underpinnings of sexual stereotyping in France, the present study sought to investigate the effects of the social variables cultural background (France vs. Maghreb), age and gender on sexual stereotyping towards gays vs. lesbians.

Despite the limitations of the present study and the remaining open questions, we showed that sexual orientation prejudice in form of more negative or less positive attitudes and associated emotion categories (joy, sadness, fear, anger, disgust) towards male vs. female homosexuality/ homosexuals in France is motivated by cultural background and gender. Results with respect to age and the type of homosexuality were less conclusive. This work should, therefore, be considered as a springboard for more detailed investigations into sexual stereotyping, both in France and across different cultures.

\section{Acknowledgments}

This study received funding from the HomoVox project (Appel à projet CNRS “Défi Genre” 2016). 


\section{Ethics Statement}

The French National Commission of Informatics and Liberties approved all protocols used in this study (CNIL Number 2-17029/UMR5554). All subjects gave written informed consent in accordance with the Declaration of Helsinki.

\section{References}

Abdaoui, A., Azé, J., Bringay, S. et al. (2017) FEEL: a French Expanded Emotion Lexicon. Language Resources \& Evaluation, 51, 833-855. https://doi.org/10.1007/s10579-016-9364-5

Adamczyk, A., \& Pitt, C. (2009). Shaping attitudes about homosexuality: The role of religion and cultural context. Social Science Research, 38, 338-351.

Al-Ghafari, I. (2002). Is there a lesbian identity in the Arab culture? Al-Raida Journal, 86-90.

Andersen, R. \& Fetner, T. (2008). Cohort Differences in Tolerance of Homosexuality: Attitudinal Change in Canada and the United States, 1981-2000. Public Opinion Quarterly, 72 (2), 311-330. http://dx.doi.org/10.1093/poq/nfn017

Anderson, J. \& Koc, Y. (2015). Exploring patterns of explicit and implicit anti-gay attitudes in Muslims and Atheists, European Journal of Social Psychology, 45, 687-701.

Bates, D., Maechler, M., Bolker, B. et al. (2021). Linear Mixed-Effects Models using 'Eigen' and S4. https://github.com/lme4/lme4/

Bertossi, C. (2016). La citoyenneté à la française. Valeur et réalités. Paris: CNRS Éditions.

Bettinsoli, M. L., Suppes, A., \& Napier, J. L. (2019). Predictors of attitudes toward gay men and lesbian women in 23 countries. Social Psychological and Personality Science, 11 (5), 697-708.

Blashill, A. and Powlishta, K. (2009). Gay stereotypes: The use of sexual orientation as a cue for gender-related attributes. Sex Roles, 61 : 783-793.

Bochow, M. (2003). Sex unter Männern oder schwuler Sex - Zur sozialen Konstruktion von Männlichkeit unter türkisch-, kurdisch- und arabischstammigen Migranten in Deutschland. Einige Anmerkungen zur Wahrnehmung des Islam in Deutschland. In M. Bochow \& R. Marbach (Eds.), Homosexualität und Islam (99-115), Hamburg: MännerschwarmSkript Verlag.

Bodenhausen, G. V., Kramer, G. P., \& Süsser, K. (1994). Happiness and stereotypic thinking in social judgment. Journal of Personality and Social Psychology, 66, 621- 632.

Borras Guevara, M. L., \& West, K. (2020). Masculinity threat: understanding why Jamaican men report more anti-gay prejudice than Jamaican women. Journal of Gender Studies, 1-14.

Bosson, J. K., Taylor, J. N., \& Prewitt-Freilino, J. L. (2006). Gender role violations and identity misclassification: The roles of audience and actor variables. Sex Roles, 55, 13-24. https://doi.org/10.1007/s11199-006-9056-5

Bosson, J. K., Weaver, J. R., Caswell, T. A., \& Burnaford, R. M. (2011). Gender threats and men's antigay behaviors: The harmful effects of asserting heterosexuality. Group Processes \& Intergroup Relations, 15, 471-486. https://doi.org/10.1177/1368430211432893 
Buck, D. M., Plant, E. A., Ratcliff, J., Zielaskowski, K., \& Boerner, P.(2013). Concern over the misidentification of sexual orientation: Social contagion and the avoidance of sexual minorities. Journal of Personality and Social Psychology, 105, 941-960. https://doi.org/10.1037/a0034145

Carstensen, L. L., \& DeLiema, M. (2018). The positivity effect: a negativity bias in youth fades with age. Current Opinion in Behavioral Cciences, 19, 7-12.

Kitzinger, C. (2005). Heteronormativity in action: reproducing the heterosexual nuclear family in after-hours medical calls, Social Problems, 52 (4), 477-498, https://doi.org/10.1525/sp.2005.52.4.477

Ciocca, G., Niolu, C., Déttore, D., Antonelli, P., Conte, S., Tuziak, B., . . Jannini, E. A. (2017). Crosscultural and socio-demographic correlates of homophobic attitude among university students in three European countries. Journal of Endocrinological Investigation, 40, 227-233.

Damasio, A. R. (1994). Descartes'error. New York: Avon Books.

Davies, M. (2004). Correlates of negative attitudes toward gay men: Sexism, male role norms, and male sexuality. Journal of Sex Research, 41, 259-266.

Deaux, K., \& Lewis, L. L. (1984). Structure of gender stereotypes: Interrelationships among components and gender label. Journal of Personality and Social Psychology, 46, 991-1004.

Eagly, A. H., \& Mladinic, A. (1989). Gender stereotypes and attitudes toward women and men. Personality and Social Psychology Bulletin, 15, 543-558.

Equality and Human Rights Commission (2020). Sexual orientation discrimination. Retrieved from https://www.equalityhumanrights.com/en/advice-and-guidance/sexual-orientation-discrimination

De Castilho, R. E., Mujdricza-Maydt, E., Yimam, S. M., Hartmann, S., Gurevych, I., Frank, A., \& Biemann, C. (2016). A web-based tool for the integrated annotation of semantic and syntactic structures. In Proceedings of the Workshop on Language Technology Resources and Tools for Digital Humanities (LT4DH) (pp. 76-84).

Fasoli, F. \& Maass, A. (2020). The social costs of sounding gay: voice-based impressions of adoption applicants. Journal of Language and Social Psychology, 39 (1), 112-131.

Fasoli, F., Maass, A., Paladino, M. P. \& Sulpizio, S. (2017). Gay- and lesbian-sounding auditory cues elicit stereotyping and discrimination, Archives of Sexual Behavior, 46 (5), 1261-1277.

Feng, Y., Lou, C., Gao, E., Tu, X., Cheng, Y., Emerson, M. R., \& Zabin, L. S. (2012). Adolescents' and young adults' perceptions of homosexuality and related factors in three Asian cities. Journal of Adolescent Health, 50 (3), S52-S60.

Fronhofer, N. M. (2020). Emotion Concepts in Context - A Contrastive Analysis of English and German Discourse. Doctoral Dissertation, University of Augsburg, Germany.

Glick, P., Gangl, C., Gibb, S., Klumpner, S. \& Weinberg, E. (2007). Defensive reactions to masculinity threat: More negative affect toward effeminate (but not masculine) gay men. Sex Roles, 57, 55-59.

Gordon, A. R., \& Meyer, I. H. (2007). Gender nonconformity as a target of prejudice, discrimination, and violence against LGB individuals. Journal of LGBT Health Research, 3, 55-71.

Gowen, C. W., \& Britt, T. W. (2006). The interactive effects of homosexual speech and sexual orientation on the stigmatization of men: Evidence for expectancy violation theory. Journal of Language and Social Psychology, 25 (4), 437-456.

Grijalva, E., Newman, D. A., Tay, L., Donnellan, M. B., Harms, P. D., Robins, R. W., \& Yan, T. (2015). Gender differences in narcissism: a meta-analytic review. Psychological Bulletin, 141 (2), 261310. 
Habarth, J. M. (2015). Development of the heteronormative attitudes and beliefs scale. Psychology \& Sexuality, 6 (2), 166-188. https://doi.org/10.1080/19419899.2013.876444

Herek, G. M. (1986). On heterosexual masculinity: Some psychical consequences of the social construction of gender and sexuality. The American Behavioral Scientist, 29, 563-577. https://doi.org/10.1177/000276486029005005

Herek, G. M. (2000). Sexual prejudice and gender: Do heterosexuals' attitudes toward lesbians and gay men differ? Journal of Social Issues, 56, 251-266.

Herek, G. M. (2000). The psychology of sexual prejudice. Current Directions in Psychological Science, 9 (1), 19-22.

Herek, G. M. (2002). Gender gaps in public opinion about lesbians and gay men. Public Opinion Quarterly, 66, 40-66.

Herek, G. M. (2004). Beyond "homophobia": Thinking about sexual prejudice and stigma in the twenty-first century. Sexuality Research \& Social Policy, 1(2), 6-24.

Herek, G. M. (2016). The Social Psychology of Sexual Prejudice. In T. D. Nelson (Ed.), Handbook of Prejudice, Stereotyping, and Discrimination (355-384), Psychology Press.

Herek, G.M. (2007). Confronting Sexual Stigma and Prejudice: Theory and Practice. Journal of Social Issues, 63, 905-925.

Mendos, L.R., Botha, K., Carrano Lelis,R., López de la Peña, E., Savelev, I. \& Tan, D. (2020). StateSponsored Homophobia 2020: Global Legislation Overview Update (ILGA World, Geneva), Retrieved from https://ilga.org/state-sponsored-homophobia-report-2020-global-legislation-overview

Inglehart, R., C. Haerpfer, A. Moreno, C. Welzel, K. Kizilova, J. Diez-Medrano, M. Lagos, P. Norris, E. Ponarin \& B. Puranen et al. (Eds.). (2014). World Values Survey: Round Six - Country-Pooled Datafile Version: https://www.worldvaluessurvey.org/WVSDocumentationWV6.jsp. Madrid: JD Systems Institute

INSEE, Institut Nationale de la Statistique et des Etudes Economiques (2021). Retrieved from https://www.insee.fr/fr/statistiques/3633212

Jäckle, S., Wenzelburger, G. (2015). Religion, religiosity, and the attitudes toward homosexuality - a multilevel analysis of 79 countries. Journal of Homosexuality, 62 (2), 207-241.

Jackson, S. E., Hackett, R. A., Grabovac, I., Smith, L., \& Steptoe, A. (2019). Perceived discrimination, health and wellbeing among middle-aged and older lesbian, gay and bisexual people: A prospective study. PLoS One, 14 (5), e0216497. https://doi.org/10.1371/journal.pone.0216497

Jost, J. T., \& Banaji, M. R. (1994). The role of stereotyping in system-justification and the production of false consciousness. British Journal of Social Psychology, 33 (1), 1-27. https://doi.org/10.1111/j.2044-8309.1994.tb01008.x.

Keiller, S. W. (2010). Masculine norms as correlates of heterosexual men's attitudes toward gay men and lesbian women. Psychology of Men \& Masculinity, 11 (1), 38.

Kiss, M. J., Morrison, M. A., \& Morrison, T. G. (2018). A meta-analytic review of the association between disgust and prejudice toward gay men. Journal of Homosexuality, 67 (5), 1-23. https://doi.org/10.1080/00918369.2018.1553349

Kite, M. E., \& Whitley, B. E., Jr. (1998). Do heterosexual women and men differ in their attitudes toward homosexuality? A conceptual and methodological analysis. In G. M. Herek (Ed.), Stigma and Sexual orientation: Understanding Prejudice Against Lesbians, Gay Men, and Bisexuals (39-61). Newbury Park, CA: Sage. 
Kitzinger, C. (2005). Heteronormativity in action: Reproducing the heterosexual nuclear family in after-hours medical calls. Social Problems, 52 (4), 477-498. https://doi.org/10.1525/sp.2005.52.4.477

Kligerman, N. (2007). Homosexuality in Islam: a difficult paradox. Macalester Islam Journal, 2 (3), 52-64.

Kooli, N., \& Pigneul, E. (2018). Analyse de sentiments à base d'aspects par combinaison de réseaux profonds: application à des avis en français (A combination of deep learning methods for aspect-based sentiment analysis: application to French reviews). In Actes de la Conférence TALN. Volume 1-Articles longs, articles courts de TALN (303-310).

LaMar, L., \& Kite, M. (1998). Sex differences in attitudes toward gay men and lesbians: A multidimensional perspective. Journal of Sex Research, 35 (2), 189-196.

Lankester, L. A., \& Alexopoulos, T. (2021). From Diversity Ideologies to the Expression of Stereotypes: Insights Into the Cognitive Regulation of Prejudice Within the Cultural-Ecological Context of French Laïcité. Frontiers in Psychology, 11, 3806. https://doi.org/10.3389/fpsyg.2020.591523

Lehavot, K., \& Lambert, A. J. (2007). Toward a greater understanding of antigay prejudice: On the role of sexual orientation and gender role violation. Basic and Applied Social Psychology, 29 (3), 279292.

Leslie, L. M., Bono, J. E., Kim, Y. S., \& Beaver, G. R. (2020). On melting pots and salad bowls: A meta-analysis of the effects of identity-blind and identity-conscious diversity ideologies. Journal of Applied Psychology, 105 (5), 453-471.

Lick, D. J., \& Johnson, K. L. (2015). Intersecting race and gender cues are associated with perceptions of gay men's preferred sexual roles. Archives of Sexual Behavior, 44 (5), 1471-1481.

Lingiardi, V., Falanga, S., \& D’Augelli, A. R. (2005). The evaluation of homophobia in an Italian sample. Archives of Sexual Behavior, 34 (1), 81-93.

McDermott, R. C., Schwartz, J. P., Lindley, L. D. \& Proietti, J. S. (2013). Exploring men's homophobia: associations with religious evolutionary psychology fundamentalism and gender role conflict domains. Psychology of Men \& Masculinity, 15 (2), 191-200.

Miller, A. E. (2018). Searching for gaydar: blind spots in the study of sexual orientation perception. Psychology \& Sexuality, 9 (3), 188-203.

Mohammad, S. M. (2021). Sentiment analysis: automatically detecting valence, emotions, and other affectual states from text. In Emotion Measurement (323-379). Woodhead Publishing.

Mohammad, S.M. \& Turney, P.D. (2013). Crowdsourcing a word-emotion association lexicon. Computational Intelligence, 29, 436-465.

Mohammad, S., \& Yang, T. (2011). Tracking sentiment in mail: How genders differ on emotional axes. In Proceedings of the 2nd Workshop on Computational Approaches to Subjectivity and Sentiment Analysis (WASSA 2.011) (70-79). Portland, Oregon: Association for Computational Linguistics.

Montero, C. S., Munezero, M., \& Kakkonen, T. (2014). Investigating the role of emotion-based features in author gender classification of text. In International Conference on Intelligent Text Processing and Computational Linguistics (98-114). Berlin, Heidelberg: Springer.

Moussawi, G. (2011). Not “straight," but still a "man”. Negotiating non-heterosexual masculinities in Beirut. In S. Seidman, N. Fischer \& C., Meeks. Introducing the New Sexuality Studies (159-165). London and New York: Routledge.

Nagoshi, C. T., Cloud, J. R., Lindley, L. M., Nagoshi, J. L., \& Lothamer, L. J. (2019). A test of the three-component model of gender-based prejudices: homophobia and transphobia are affected by 
raters' and targets' assigned sex at birth. Sex Roles, 80, 137-146. https://doi.org/10.1007/s11199$\underline{018-0919-3}$

OCDE (2019) Le panorama de la société 2019: les indicateurs sociaux de l'OCDE. Retrieved from https://www.oecd.org/fr/els/soc/SaG2019-chapitre1-Eclairage-LGBT.pdf

Paroubek, P., Grouin, C., Bellot, P., Claveau, V., Eshkol-Taravella, I., Fraisse, A., ... \& Torres-Moreno, J. M. (2018, May). DEFT2018: recherche d'information et analyse de sentiments dans des tweets concernant les transports en Île de France. In DEFT 2018-14ème atelier Défi Fouille de Texte (Vol. 2, pp. 1-11).

Parrott, D. J. (2009). Aggression toward gay men as gender role enforcement: Effects of male role norms, sexual prejudice, and masculine gender role stress. Journal of personality, 77 (4), 1137-1166. https://doi.org/10.1111/j.1467-6494.2009.00577.x

Parrott, D. J., \& Peterson, J. L. (2008). What motivates hate crimes based on sexual orientation? Mediating effects of anger on antigay aggression. Aggressive Behavior, 34 (3), 306-318. https://doi.org/10.1002/ab.20239

Pistella, J., Tanzilli, A., Ioverno, S., Lingiardi, V., \& Baiocco, R. (2018). Sexism and attitudes toward same-sex parenting in a sample of heterosexuals and sexual minorities: The mediation effect of sexual stigma. Sexuality Research and Social Policy, 15 (2), 139-150.

Podesva, R. J., Roberts, S. J. \& Campbell-Kibler, K. (2001). Sharing resources and indexing meanings in the production of gay styles. In: K. Campbell-Kibler, R.J. Podesva, S.J. Roberts, \& A. Wong (Eds.), Language and sexuality: Contesting meaning in theory and practice (175-187), CSLI Publications.

Poteat, V. P., \& Anderson, C. J. (2012). Developmental changes in sexual prejudice from early to late adolescence: The effects of gender, race, and ideology on different patterns of change. Developmental Psychology, 48 (5), 1403-1415.

Pratto, F., Sidanius, J., \& Levin, S. (2006). Social dominance theory and the dynamics of intergroup relations: Taking stock and looking forward. European Review of Social Psychology, 17 (1), 271-320. https://doi.org/10.1080/10463280601055772

Proulx, R. (1997). Homophobia in northeastern Brazilian university students. Journal of Homosexuality, 34 (1), 47-56.

Ray, T. N., \& Parkhill, M. R. (2021). Heteronormativity, disgust sensitivity, and hostile attitudes toward gay men: potential mechanisms to maintain social hierarchies. Sex Roles, 84 (1), 49-60.

Reese, G., Steffens, M. C., \& Jonas, K. J. (2014). Religious affiliation and attitudes towards gay men: On the mediating role of masculinity threat. Journal of Community \& Applied Social Psychology, 24 (4), 340-355.

Rudman, L. A., \& Fairchild, K. (2004). Reactions to counterstereotypic behavior: the role of backlash in cultural stereotype maintenance. Journal of Personality and Social Psychology, 87 (2), 157-176.

Rule, N. O., \& Alaei, R. (2016). "Gaydar” the perception of sexual orientation from subtle cues. Current Directions in Psychological Science, 25 (6), 444-448.

Sakallı-Uğurlu, N. and Uğurlu, O. (2016). Predicting attitudes toward gay men with ambivalence toward men, questioning religion, and gender differences. Sex Roles, 74 (5-6), 195-205.

Schiller, M., Lang, C., Schönwälder, K. et al. (2020). Vielfalt and diversité: how local actors in France and Germany evaluate immigration and socio-cultural heterogeneity. Comparative Migration Studies, 8, 48. https://doi.org/10.1186/s40878-020-00205-1 
Schwarz, N., \& Clore, G. L. (1996). Feelings and phenomenal experiences. In E. T. Higgins \& A. W. Kruglanski (Eds.), Social Psychology: Handbook of Basic Principles (433-465). New York: Guilford Press.

Scull, N. C., \& Mousa, K. (2017). A phenomenological study of identifying as lesbian, gay and bisexual in an Islamic country. Sexuality \& Culture, 21 (4), 1215-1233.

Sherkat, D.E., Powell-Williams, M., Maddox, G. \& De Vries, K.M. (2011). Religion, politics, and support for same-sex marriage in the United States, 1988-2008. Social Science Research 40 (1), 167180.

Simon, B. (2008). Einstellungen zur Homosexualität: Ausprägungen und psychologische Korrelate bei Jugendlichen ohne und mit Migrationshintergrund (ehemalige UdSSR und Türkei). Zeitschrift für Entwicklungspsychologie und Pädagogische Psychologie, 40(2), 87-99.

Simon, P. (2013). Contested citizenship in France: the republican politics of identity and integration. In A. Cola, S. Meunier, \& V. Tiberj (Eds.), Developments in French politics, Vol 5 (203-217). Basingstoke: Palgrave Macmillan.

Silge, J. \& Robinson, D. (2017). Textmining With R. A Tidy Approach. Sebastopol, CA: O'Reilly Media, Inc.

Sirin, S. R., McCreary, D. R., \& Mahalik, J. R. (2004). Differential reactions to men and women's gender role transgressions: perceptions of social status, sexual orientation, and value dissimilarity. The Journal of Men's Studies, 12 (2), 119-132.

Siraj, A. (2006). The Islamic concepts of masculinity and femininity. Doctoral dissertation, University of Glasgow, United Kingdom.

Smith, T.W., Son, J., Kim, J. (2014). Public Attitudes toward Homosexuality and Gay Rights across Time and Countries. NORC at the University of Chicago and The Williams Institute. Retrieved from https://escholarship.org/content/qt4p93w90c/qt4p93w90c.pdf

Span, S. A., \& Vidal, L. A. (2003). Cross-cultural differences in female university students' attitudes toward homosexuals: A preliminary study. Psychological Reports, 92 (2), 565-572.

Nzali, M. D. T., Abdaoui, A., Azé, J., Bringay, S., Lavergne, C., Mollevi, C., \& Poncelet, P. (2017, June). Frenchsenticlass: un système automatisé pour la classification de sentiments en français. In DEFT: Défi Fouille de Texte.

Taylor, D. M., \& Raadt, J. S. 2021. Gay-and straight-sounding auditory cues elicit stereotyping about teaching effectiveness. Journal of Research in Music Education, 69 (1). https://doi.org/10.1177/0022429420948229

Theodore, P. S., \& Basow, S. A. (2000). Heterosexual masculinity and homophobia: a reaction to the self? Journal of Homosexuality, 40 (2), 31-48. https://doi.org/10.1300/J082v40n02 03

Todd, A. R., \& Galinsky, A. D. (2012). The reciprocal link between multiculturalism and perspectivetaking: How ideological and self-regulatory approaches to managing diversity reinforce each other. Journal of Experimental Social Psychology, 48 (6), 1394-1398.

Valentova, J. V. \& Havliček, J. (2013). Perceived sexual orientation based on vocal and facial stimuli is linked to self-rated sexual orientation in Czech men, PLoS One, 8 (12), e82417.

Valentova, J. V., Rieger, G., Havlicek, J., Linsenmeier, J. A. W. \& Bailey, J. M. (2011). Judgments of sexual orientation and masculinity - femininity based on thin slices of behavior: a cross-cultural comparison, Archives of Sexual Behavior, 40 (6), 1145-1152.

van den Akker, H., van der Ploeg, R., \& Scheepers, P. (2013). Disapproval of homosexuality: comparative research on individual and national determinants of disapproval of homosexuality in 20 European countries. International Journal of Public Opinion Research, 25 (1), 64-86. 
1133 van Leeuwen, F., Miton, H., Firat, R. B. \& Boyer, P. (2016). Perception of Gay Men as Defectors and 1134 Commitment to Group Defense Predict Aggressive Homophobia. Evolutionary Psychology, 14 (3), 111358.

1136 Vandello, J. A., Bosson, J. K., Cohen, D., Burnaford, R. M., \& Weaver, J. R. (2008). Precarious 1137 manhood. Journal of Personality and Social Psychology, 95 (6), 1325-1339.

1138

1139 Verkuyten, M. \& Yogeeswaran, K. (2020). Cultural diversity and its implications for intergroup 1140 relations. Current Opinion in Psychology, 32, 1-5.

1141 Whitley, B. E. (2001). Gender-role variables and attitudes toward homosexuality. Sex Roles, 45 (11), 1142 691-721.

1143

1144 Whitley, B. E. (2009). Religiosity and attitudes toward lesbians and gay men: A meta-analysis. 1145 International Journal for the Psychology of Religion, 19 (1), 21-38.

1146

1147 Whitley, B. E., \& Ægisdóttir, S. (2000). The gender belief system, authoritarianism, social dominance 1148 orientation, and heterosexuals' attitudes toward lesbians and gay men. Sex Roles, 42 (11), 947-967. 1149 https://doi.org/10.1023/A:1007026016001

1150 Yimam, S. M., de Castilho, R. E., Gurevych, I. \& Biemann, C. (2014). Automatic annotation 1152 suggestions and custom annotation layers in webanno. Proceedings of $52^{\text {nd }}$ Annual Meeting of the Association for Computational Linguistics: System Demonstrations, 91-96.

1155 Yep, G. A. (2003). The Violence of Heteronormativity in Communication Studies, Journal of 1156 Homosexuality, 45 (2-4), 11-59. 


\section{Appendix}

Table 1. French-French negative polarity items.

\begin{tabular}{|l|l|}
\hline NOUNS & $\begin{array}{l}\text { victime, crétin, difficulté, manifestation, attentat, pédé, homophobie, tare, problème, } \\
\text { rejet, réticent, combat }\end{array}$ \\
\hline $\begin{array}{l}\text { ADJECTIVES } \\
\text { (\& adverbs) }\end{array}$ & $\begin{array}{l}\text { (c’est) dommage, mal, choqué, pas naturel, virulent, (pas) accepté, mauvais, difficile, } \\
\text { triste, négatif, (pas) d'accord, contre, frustrant, pas facile, compliqué, (pas) commun, } \\
\text { moins bien, mal vu, condamné, inégal, étrange }\end{array}$ \\
\hline VERBS & $\begin{array}{l}\text { persécuter, détruire, marcher, choquer, rejeter, bannir, insulter, traiter, s'énerver, être } \\
\text { contre, (trop) s'afficher, condamner, cacher, oser, mettre au rebut, protester, aller à } \\
\text { l'encontre, gêner }\end{array}$ \\
\hline
\end{tabular}

Table 2. French-Maghrebian negative polarity items.

\begin{tabular}{|l|l|}
\hline NOUNS & $\begin{array}{l}\text { truc, tiquer, menace, péché, (pas) plaisir, histoire, barrière, dégoût, nature, obstacle, } \\
\text { crime, tabou, insulte, origine, changement, réaction, perturbation, (pas) principes, } \\
\text { problème, intolérance, gêne, maladie, sujet, direction, manière, (pas) envie, exception, } \\
\text { personne, rejet, isolement, souffrance, lesbienne, bisexuelle, milieu, genre, choix, gens, } \\
\text { trouble, distance, cause, liberté, fréquentation, parent, développement, éducation, } \\
\text { jeunesse, chose, prise en charge, anti-naturage, logique, péché, religion, châtiment, } \\
\text { psychologue, déséquilibre, catégorie }\end{array}$ \\
\hline $\begin{array}{l}\text { ADJECTIVES } \\
\text { (\& adverbs) }\end{array}$ & $\begin{array}{l}\text { bizarre, (pas) habitué, surprenant, (pas bien) perçu, pas normal, homophobe, difficile, } \\
\text { (pas) justifié, (pas) accepté, grave, dégoûté, (pas) permis, (pas) toléré, tabou, (pas) } \\
\text { fréquent, interdit, (il n’y a pas) beaucoup, rare, (être) fait, mal vu, rejeté, stigmatisé, } \\
\text { nouveau, contre (la nature), être gêné, développé, exceptionnel, mal, contraire, pas } \\
\text { courant, dommage, dehors, illicite, illogique, pas bien, dégoûté, pas compréhensible, } \\
\text { absent, malade, conçu, anormal, (contre la) relation (homme/ femme), contre la) } \\
\text { biologie (humaine) }\end{array}$ \\
\hline VERBS & $\begin{array}{l}\text { casser, perturber, avoir mal, déranger, (pas) devoir, pas entraver, dégoûter, critiquer, (pas) } \\
\text { comprendre, être contre, souffrir, quitter, (pas) aimer, (pas en) parler, (pas) être pour, } \\
\text { cacher, (pas) montrer, (ne pas) être à l’aise, (pas) tolérer, (pas) accepter, (pas) pratiquer, } \\
\text { (pas) voir, être à contre-courant, affecter quelqu'un, dépasser quelqu'un, éviter, détester, } \\
\text { (pas avoir) envie, (pas) plaire, (pas) se faire, cautionner, porter, (ne pas) être } \\
\text { (homosexuel), déranger, infecter, (pas) vouloir, gêner, agresser, violer, (pas y) avoir } \\
\text { (autant), chambouler, (pas) connaître, (pas) rencontrer, (pas) faire }\end{array}$ \\
\hline
\end{tabular}


Table 3. French-French positive polarity items.

\begin{tabular}{|l|l|}
\hline NOUNS & $\begin{array}{l}\text { câlin, amour, pote, copain, modernité, avancement, progrès, liberté, victoire, partage, } \\
\text { baiser, énergie, mystère, être aimé, amitié, bonheur, indifférence, ami, joie, sourire, } \\
\text { temps, caresse, sexualité, tendresse, célébrations, excitation, sensualité, délicatesse, } \\
\text { simplicité, bisou, plaisir, euphorie, bonne humeur, bien-être, satisfaction, beaucoup } \\
\text { d'attention, soleil, corps, pureté, amour, acceptation, forme, choix, vision, nature, } \\
\text { attirance, vie, admiration, douceur, désir, amélioration, monnaie courante, avancés, } \\
\text { évolutions }\end{array}$ \\
\hline ADJECTIVES & $\begin{array}{l}\text { heureux, amoureux, bon, normal, riche, amical, content, naturel, habitué, bien, attiré, } \\
\text { souriant, agréable, joli, sensuel, tendre, doux, ouvert, rigolo, pur, sauvage, clair, fréquent, } \\
\text { admis, accepté, prévisionniste, ravi, beau, familier, normal, répandu, (voir) plus, } \\
\text { tolérant, toléré, libre, progressé, curieux, épanouies, plaisant, surprise, encré, juste, gay- } \\
\text { friendly, banal,courant, assumé }\end{array}$ \\
\hline VERBS & $\begin{array}{l}\text { s'embrasser, sourire, fêter, partager, avancer, être bien (ensemble), gagner, célébrer, } \\
\text { apprécier, se tuer (de rire), désirer, caresser, parler, mettre en avant, accepter, s'aimer, } \\
\text { aimer, soutenir, donner, recevoir, évoluer, respecter, être pour, etre d'accord, valoir, } \\
\text { accepter, (pas/ aucun) soucis, reconnaître, favoriser, entrer, être quotidien, avoir droit }\end{array}$ \\
\hline
\end{tabular}

1183

Table 4. French-Maghrebian positive polarity items.

\begin{tabular}{|l|l|}
\hline NOUNS & $\begin{array}{l}\text { joie, positivité, satisfaction, confiance, affection, sécurité, amour, vie, charisme, ami, } \\
\text { choix, tendresse, bonheur, princesse, désir, liberté, amour, acceptation, plaisir, une forme } \\
\text { d'amour, attirance, goûts, attirance, (pas d') inconvénient, mœurs, loi, tolérance, logique, } \\
\text { démocratie, accouplement }\end{array}$ \\
\hline ADJECTIVES & $\begin{array}{l}\text { content, banal, bien, proche, intime, d'accord, heureux, amoureux, beau, complice, } \\
\text { excitant, charmante, libre, encré, normal, enrichissant, super, agréable, gentille, tendre, } \\
\text { libre, affectueux, mignon, naturel, épanouis, heureux, bon, mieux, normalisé, pareil, } \\
\text { tolérant, attiré, fréquent, (pas) bizarre, plus toléré, compréhensif, souriant, égal, chou, } \\
\text { sympa, légitime, accepté }\end{array}$ \\
\hline VERBS & $\begin{array}{l}\text { sourire, caresser, avoir droit, s'embrasser, s'aimer, s'enlacer, câliner, s'attirer, fêter, aimer, } \\
\text { accepter, respecter, changer, souhaiter, (pas) déranger, tolérer, accepter, légaliser, (m') } \\
\text { aller, sourire, approuver, admettre, partager, faire (sa vie), décider, donner }\end{array}$ \\
\hline
\end{tabular}

